\title{
Free Radical Scavenging and Anticollagenase Properties of Sargachromanol I from Myagropsis myagroides
}

\author{
K. B. W. R. KIM, M. J. KIM ${ }^{1}$, S. M. JEONG AND D. H. AHN ${ }^{1 *}$ \\ Institute of Fisheries Sciences, Pukyong National University, Busan 46041, ${ }^{1}$ Department of Food Science and Technology/ \\ Institute of Food Science, Pukyong National University, Busan 48513, Republic of Korea
}

Kim et al.: Anticollagenase and Free Radical Scavenging Properties of Sargachromanol I

\begin{abstract}
The present study investigated the free radical scavenging activity and antiwrinkle properties of methanol extract, hexane, chloroform, ethyl acetate, and butanol partition fractions of Myagropsis myagroides. The methanol extract showed higher free radical scavenging $(65.46 \%$ at $0.5 \mathrm{mg} / \mathrm{ml})$ and collagenase inhibitory activity $(29.64 \%$ at $1000 \mu \mathrm{g} / \mathrm{ml})$ than the water extract $(16.68 \%$ at $0.5 \mathrm{mg} / \mathrm{ml}$ and $<5 \%$ at $1000 \mu \mathrm{g} / \mathrm{ml})$. The hexane fraction exhibited strong free radical scavenging activity $(96.36 \% \mathrm{at} 0.5 \mathrm{mg} / \mathrm{ml})$ and collagenase inhibitory activity $\left(\mathrm{IC}_{\mathbf{5 0}}\right.$ of $\left.712.21 \mu \mathrm{g} / \mathrm{ml}\right)$. The hexane fraction was subjected to silica gel column chromatography, Sephadex LH-20 column chromatography, octadecyl silica Sepak cartridge, and preparative high performance liquid chromatography. Sargachromaol I was isolated, which showed strong free radical scavenging activity $(95.82 \%$ at $0.1 \mathrm{mg} / \mathrm{ml})$ and collagenase inhibitory activity $\left(\right.$ IC $_{50}$ value of $54.01 \mu \mathrm{g} / \mathrm{ml})$. The potential value in preventing skin aging could be confirmed through effects of extract from Myagropsis myagroides on free radical scavenging activity and collagenase inhibitory properties.
\end{abstract}

Key words: Myagropsis myagroides, sargachromanol I, collagenase inhibitory activity, free radical scavenging activity

The process of skin aging is divided into intrinsic and extrinsic aging. Intrinsic skin aging is caused by physiological changes in the elasticity of the skin over time. Extrinsic skin aging occurs predominately because of chronic exposure to sunlight (photoaging) $)^{[1]}$. UV exposure causes physical changes to the skin via alterations to the connective tissue, resulting from the accumulation of reactive oxygen species (ROS) ${ }^{[2]}$, which cause lipid peroxidation and damage to cellular contents and enzymes ${ }^{[3]}$.

Collagen accounts for about $90 \%$ of the extracellular matrix in human dermis. Type I collagen accounts for more than $80 \%$ of the total collagen, and changes in its structure have been considered as a major cause of skin aging and wrinkle formation ${ }^{[4]}$. Collagenases belong to the family of matrix metalloproteinases (MMPs), the transmembrane zinc endopeptidase enzymes. These play important roles in many processes including tissue modification, tissue homeostasis and repair after wounding by digesting collagen and elastin fibers ${ }^{[5]}$. However, excessive activation due to photoaging and chronic aging leads to alterations in gelatin, collagen and elastin composition, resulting in wrinkles, laxity, sagging and a rough appearance of the human $\operatorname{skin}^{[6,7]}$. Thus, agents that inhibit collagenase activity might have beneficial effects in maintaining healthy skin by preventing dermal matrix alteration.

This is an open access article distributed under the terms of the Creative Commons Attribution-NonCommercial-ShareAlike 3.0 License, which allows others to remix, tweak, and build upon the work non-commercially, as long as the author is credited and the new creations are licensed under the identical terms

Accepted 23 March 2019

Revised 28 November 2018

Received 04 September 2018

Indian J Pharm Sci 2019;81(3):561-565 
Myagropsis myagroides of the family Sargassaceae, Phaeophyta, grows in the East Asian coast subtidal zone. Studies on M. myagroides revealed mainly antiinflammatory ${ }^{[8]}$, antihypertensive ${ }^{[9]}$, anticoagulant ${ }^{[10]}$ and hepatoprotective activities ${ }^{[11]}$. Sagachromanols (1 16) were isolated from the brown alga Sargassum siliquastrum as novel bioactive substances ${ }^{[12]}$. In a previous study ${ }^{[13]}$, sargachromanol I was isolated from M. myagroides, which inhibited amylase activity. In this study, in vitro anticollagenase and free radical scavenging activities of $M$. myagroides extracts were investigated, particularly the hexane fraction, and the isolated active compound sargachromanol I.

M. myagroides was collected from the subtidal zone at Song-Jung, Busan, Korea, lyophilized and finely powdered, extracted 3 times with methanol for $24 \mathrm{~h}$ at room temperature and filtered. The combined filtrate was concentrated on a rotary evaporator (RE 200, Yamato Co., Tokyo, Japan) at $37^{\circ}$ to yield $\sim 5.7 \%$ (based on the weight of the dried M. myagroides) of extract.

The methanol extract ( $85 \mathrm{~g}$ ) was sequentially partitioned into hexane, chloroform, ethyl acetate and butanol. The active hexane fraction (13 g) was chromatographed on a silica gel column (70-230 mesh; Merck Art, Darmstadt, Germany; $5 \times 10 \mathrm{~cm}$ ) and successively eluted with a stepwise gradient of chloroform/methanol $(100: 1,50: 1,20: 1,5: 1,1: 1 \mathrm{v} / \mathrm{v})$. The fraction eluted with $50: 1 \mathrm{v} / \mathrm{v}$ chloroform/methanol was subsequently subjected to Sephadex LH-20 column chromatography (Amersham Pharmacia Biotech AB, Uppsala, Sweden; $2.5 \times 90 \mathrm{~cm}$ column; chloroform:methanol, $1: 1 \mathrm{v} / \mathrm{v}$ ) and two fractions obtained (fraction 1 and 2) were further subjected to silica gel thin-layer chromatography (No. 5744, Merck, Darmstadt, Germany). Fraction 2 was separated into 5 fractions (fraction 3 to 7) using an octadecyl silica (ODS) Sepak cartridge (SPE C18 $10 \mathrm{~g}$, Grace, IL, USA; 60-90 \% methanol). The active fraction 4 was successively subjected to Sephadex LH-20 column chromatography (methanol) and an ODS Sepak cartridge (50-60\% methanol). Each fraction was separated into six fractions (fractions 4-1 to 4-6) using ODS high-performance liquid chromatography (HPLC; ODS column i.d. $4.6 \times 150 \mathrm{~mm} ; 50-100 \%$ aqueous methanol gradient, $1 \mathrm{ml} / \mathrm{min})$. Finally, the fraction 4-2 was purified using preparative HPLC (Cosmosil 5C18-MS II; $10 \times 150 \mathrm{~mm}$ column, Nacalai Tesque, Kyoto, Japan; $70 \%$ aqueous methanol, $9 \mathrm{ml} / \mathrm{min}$ ) to isolate sargachromanol I (52 mg). Sargachromanol I was identified using nuclear magnetic resonance
(NMR). The following signals were obtained, ${ }^{1} \mathrm{H}$ NMR $\left(600 \mathrm{MHz}, \mathrm{CDCl}_{3}\right) 6.37(1 \mathrm{H}, \mathrm{d}, 1.4 \mathrm{~Hz}), 5.27(1 \mathrm{H}, \mathrm{s})$, $6.47(1 \mathrm{H}, \mathrm{d}, 2.8 \mathrm{~Hz}), 5.11(1 \mathrm{H}$, br t, $6.5 \mathrm{~Hz}), 4.87(1 \mathrm{H}$, dd, 9.7, $3.4 \mathrm{~Hz}), 3.91(1 \mathrm{H}, \mathrm{d}, 3.4 \mathrm{~Hz}), 4.97(1 \mathrm{H}$, br d, $9.6 \mathrm{~Hz}) ;{ }^{13} \mathrm{C} \mathrm{NMR}\left(150 \mathrm{MHz}, \mathrm{CDCl}_{3}\right) 75,31.3,22.4$, $121.1,112.6,147.9,115.6,127.1,39.5,22.1,124.8$, $134.3,39.4,25.2,33.4,41.2,214.6,74.3,120.9,140$, 25.9, 18.6, 16, 15.6, 24, 16.

Collagenase inhibitory activity was evaluated according to the method of Wunsch and Heindrich ${ }^{[14]}$ with slight modification. Briefly, calcium chloride (4 mM) dissolved in $0.1 \mathrm{M}$ Tris- $\mathrm{HCl}$ buffer ( $\mathrm{pH} 7.5)$ was used as the final buffer, and substrate 4-phenylazobenzyloxycarbonyl-Pro-Leu-Gly-Pro-D-Arg $(0.3 \mathrm{mg} /$ $\mathrm{ml})$ was dissolved in the buffer. Then $250 \mu \mathrm{l}$ of the substrate solution and $100 \mu \mathrm{l}$ of sample were combined in a tube. Clostridium histolyticum collagenase (SigmaAldrich Co. St. Louis, MO, USA) was dissolved in the final buffer at a concentration of $0.2 \mathrm{mg} / \mathrm{ml}$, and $150 \mu \mathrm{l}$ was added to the substrate-sample mixture. After incubation at room temperature for $20 \mathrm{~min}$, the reaction was stopped by adding $6 \%$ citric acid. The reaction mixture was separated by adding ethyl acetate. The absorbance of the supernatant was measured at $320 \mathrm{~nm}$. Epigallocatechin gallate (EGCG) was used as the positive control. Percent inhibition was calculated using the following Eqn., collagenase inhibition activity $(\%)=($ Abs of control-Abs of sample $) /$ Abs of control $) \times 100$.

The DPPH radical scavenging assay was performed according to the method described by Blois ${ }^{[15]}$ with a slight modification, which briefly was, $0.5 \mathrm{ml}$ of sample was mixed with $0.5 \mathrm{ml}$ of $0.2 \mathrm{M}$ DPPH solution in methanol. The mixture was then left to stand for $30 \mathrm{~min}$ at room temperature in the dark. Butylated hydrozytoluene (BHT) was used as a positive control and the negative control was methanol and $0.2 \mathrm{M} \mathrm{DPPH}$ in methanol but without sample. The absorbance of the resulting solution was measured at $517 \mathrm{~nm}$ and DPPH radical scavenging activity was calculated using the following Eqn., DPPH radical scavenging activity $(\%)=$ (1-(Abs sample/Abs negative control) $\times 100$.

The data were analysed using one-way analysis of variance with paired t-test and Duncan's multiple range test. Values are presented as the mean \pm standard deviation. Probability values (p) of less than 0.05 were considered to be significant.

The DPPH radical scavenging activities of hexane, chloroform, ethyl acetate, butanol, and water fractions 
are shown in Table 1. The hexane, chloroform, and ethyl acetate fractions showed high free radical scavenging activities. The hexane fraction produced $96.36,94.18$, and $52.77 \%$ scavenging at 500, 100, and $50 \mu \mathrm{g} / \mathrm{ml}$, respectively, and the chloroform fraction, $95.93,90.25$ and $60.36 \%$, respectively. Finally, the free radical scavenging activity of the ethyl acetate fraction was $94.59,94.50$, and $73.18 \%$, respectively. However, the butanol and water fractions exhibited lower free radical scavenging activities compared to the methanol extract. Although the chloroform and ethyl acetate fractions exhibited higher activities than the hexane fraction, their yields were lower than that of the hexane fraction. Therefore, the hexane fraction was selected for further fractionated. It was subjected to silica gel chromatography. The active chloroform:methanol $(50: 1, \mathrm{v} / \mathrm{v})$ fraction was further purified by a series of techniques such as Sephadex LH-20 column chromatography, ODS Sepak cartridge chromatography, and preparative HPLC. Ultimately, an active compound, sargachromanol I was isolated from the hexane fraction (fig. 1).

Sargachromanol I had a DPPH radical scavenging activity of $91.26 \%$ at $5 \mu \mathrm{g} / \mathrm{ml}$ (Table 2). Its activity was approximately seven times higher than that of BHT, the positive control. Jang et al. ${ }^{[12]}$ reported that sargachromanol I from Sargassum siliquastrum exerted free radical scavenging activity of $83.20 \%$ at $100 \mu \mathrm{g} / \mathrm{ml}$, and sargachromanol I previously reported to

TABLE 1: DPPH RADICAL SCAVENGING EFFECT OF DIFFERENT FRACTIONS FROM MYAGROPSIS MYAGROIDES METHANOL EXTRACT

\begin{tabular}{lccc}
\hline & \multicolumn{3}{c}{ DPPH radical scavenging effect $(\%)$} \\
\cline { 2 - 4 } & $500 \mu \mathrm{g} / \mathrm{ml}$ & $100 \mu \mathrm{g} / \mathrm{ml}$ & $50 \mu \mathrm{g} / \mathrm{ml}$ \\
\hline Hexane & $96.36 \pm 0.62^{\mathrm{Aa} 1}$ & $94.18 \pm 0.14^{\mathrm{Ba}}$ & $52.77 \pm 0.39^{\mathrm{Cc}}$ \\
Chloroform & $95.93 \pm 0.82^{\mathrm{Aab}}$ & $90.25 \pm 1.85^{\mathrm{Bb}}$ & $60.36 \pm 1.11^{\mathrm{Cb}}$ \\
Ethyl acetate & $94.59 \pm 0.46^{\mathrm{Ab}}$ & $94.50 \pm 0.72^{\mathrm{Aa}}$ & $73.18 \pm 0.78^{\mathrm{Ba}}$ \\
Butanol & $14.06 \pm 0.82^{\mathrm{Ae}}$ & $5.14 \pm 0.41^{\mathrm{Be}}$ & $={ }^{2}$ \\
Water & $30.99 \pm 0.48^{\mathrm{Aa}}$ & $5.82 \pm 0.55^{\mathrm{Be}}$ & $=$ \\
Methanol & $65.46 \pm 0.20^{\mathrm{Ad}}$ & $16.35 \pm 0.59^{\mathrm{Bb}}$ & $=$ \\
BHT & $95.79 \pm 0.06^{\mathrm{Aa}}$ & $71.62 \pm 0.81^{\mathrm{BC}}$ & $48.03 \pm 0.75^{\mathrm{Cd}}$ \\
\hline
\end{tabular}

${ }^{1}$ Means in the same row (A-C) and column (a-e) bearing different superscript are significantly different by Duncan's multiple range test $(\mathrm{p}<0.05) .{ }^{2}$ Not done exhibit high antioxidant activity. However, compared to results of previous studies, results of the current study showed significantly higher free radical scavenging activity for sargachromanol I. It has been found that free radicals can oxidize nucleic acids, proteins, lipids and DNA that lead to tissue damage and cause degenerative diseases ${ }^{[16]}$. Thus free radical scavenging assay provides an important indicator of antioxidant activity for the effective use of M. myagroides.

Collagenase inhibitory activity of the crude $M$. myagroides methanol extract was 29.6 and $16.17 \%$ at 1 and $0.5 \mathrm{mg} / \mathrm{ml}$, respectively (Table 3 ). The hexane and chloroform fractions exhibited higher inhibitory activities compared to the methanol extract. In particular, the $\mathrm{IC}_{50}$ value of hexane fraction was $712 \mu \mathrm{g} / \mathrm{ml}$. Sargachromanol I inhibited collagenase with an $\mathrm{IC}_{50}$ of $54.01 \mu \mathrm{g} / \mathrm{ml}$, which was similar to that of the positive control EGCG $\left(\mathrm{IC}_{50}, 40.62 \mu \mathrm{g} / \mathrm{ml}\right.$, Table 4). A number of collagenase inhibitors isolated from higher plants were described in the literature such as flavonoids ${ }^{[17,18]}$, catechins ${ }^{[19]}$, polyphenols ${ }^{[20,21]}$, and steroids ${ }^{[22]}$. Chromenes are related to tocotrienols and are usually found in brown algae, Sargassum sp. ${ }^{[23,24]}$. Tocotrienols are hydrophobic molecules that were shown to reduce plasma cholesterol levels and other lipid- and non-lipid-related risk factors of cardiovascular disease ${ }^{[23]}$. Moreover, the phenolic hydroxyl group on the chromanol ring might react with free radicals. During the process, an inactive tocopheroxyl free radical is formed, which is converted to tocopheryl quinine ${ }^{[25,26]}$.

Collagen is a major component of many of the skin's constituents and is degraded by MMPs. MMPs are categorized as zinc-dependent endopeptidases that are

TABLE 2: DPPH RADICAL SCAVENGING EFFECT OF SARGACHROMANOL I FROM HEXANE FRACTION OF MYAGROPSIS MYAGROIDES

\begin{tabular}{lccc}
\hline & \multicolumn{3}{c}{ DPPH radical scavenging effect (\%) } \\
\cline { 2 - 4 } & $\mathbf{1 0 0} \boldsymbol{\mu g} / \mathrm{ml}$ & $\mathbf{5 0} \boldsymbol{\mu g} / \mathrm{ml}$ & $\mathbf{5} \boldsymbol{\mu g} / \mathrm{ml}$ \\
\hline Sargachromanol I & $95.82 \pm 0.13$ & $93.69 \pm 0.06$ & $91.26 \pm 1.41$ \\
BHT & $71.62 \pm 0.81^{\mathrm{A}}$ & $48.03 \pm 0.75^{\mathrm{B}}$ & $12.55 \pm 0.50^{\mathrm{C}}$ \\
\hline A
\end{tabular}

$A$ and $B$ bearing different superscript are significantly different by Duncan's multiple range test $(p<0.05)$



Fig. 1: The structure of sargachromanol I 


\begin{tabular}{lcccc}
\hline & \multicolumn{4}{c}{ Collagenase inhibitory activity $(\%)$} \\
\cline { 2 - 5 } & $1000 \mu \mathrm{g} / \mathrm{ml}$ & $500 \mu \mathrm{g} / \mathrm{ml}$ & $50 \mu \mathrm{g} / \mathrm{ml}$ & $\mathrm{IC}_{50}(\mu \mathrm{g} / \mathrm{ml})$ \\
\hline Hexane & $70.37 \pm 4.83^{\mathrm{Ab} 1}$ & $48.15 \pm 10.48^{\mathrm{Bb}}$ & $35.61 \pm 04^{\mathrm{C}}$ & $712.21 \pm 48.93$ \\
Chloroform & $47.01 \pm 4.03^{\mathrm{Ac}}$ & $19.37 \pm 4.43^{\mathrm{BC}}$ & 3 & $=$ \\
Ethyl acetate & $27.92 \pm 6.04^{\mathrm{Ad}}$ & -2 & $=$ & $=$ \\
Butanol & $8.26 \pm 0.00^{\mathrm{Ae}}$ & - & $=$ & $=$ \\
Water & $14.67 \pm 0.42^{\mathrm{Ae}}$ & - & $=$ & $=$ \\
Methanol & $29.64 \pm 0.00^{\mathrm{Ad}}$ & $16.17 \pm 2.12^{\mathrm{BC}}$ & $61.69 \pm 30$ & $40.62 \pm 2.83$ \\
EGCG & $81.37 \pm 3.55^{\mathrm{Aa}}$ & $73.91 \pm 5.51^{\mathrm{Ba}}$ &
\end{tabular}

${ }^{1}$ Means in the same row (A-C) and column (a-e) bearing different superscript in samples are significantly different by Duncan's multiple range test $(p<0.05)$, ${ }^{2}$ less than $5 \%,{ }^{3}$ not done

TABLE 4: COLLAGENASE INHIBITORY ACTIVITY OF SARGACHROMANOL I FROM HEXANE FRACTION OF MYAGROPSIS MYAGROIDES

\begin{tabular}{|c|c|c|c|c|}
\hline & \multicolumn{3}{|c|}{ Collagenase inhibitory activity (\%) } & \multirow{2}{*}{$I C_{50}(\mu \mathrm{g} / \mathrm{ml})$} \\
\hline & $500 \mu \mathrm{g} / \mathrm{ml}$ & $50 \mu \mathrm{g} / \mathrm{ml}$ & $5 \mu \mathrm{g} / \mathrm{ml}$ & \\
\hline Sargachromanol I & $72.09 \pm 2.39^{\mathrm{A} 1}$ & $46.30 \pm 0.90^{B}$ & $=2$ & $54.01 \pm 1.05$ \\
\hline EGCG & $73.91 \pm 5.51^{\mathrm{A}}$ & $61.69 \pm 4.30^{\mathrm{A}}$ & $36.99 \pm 4.76^{B}$ & $40.62 \pm 2.83$ \\
\hline
\end{tabular}

${ }^{1}$ Means in the same row (A-B) bearing different superscripts are significantly different by Duncan's multiple range test $(p<0.05)$, ${ }^{2}$ not done

secreted as pro-MMPs ${ }^{[27]}$. Collagenases specifically degrade collagen fibers ${ }^{[28]}$. It is proposed that the deprotonation of thehydroxylgroupsofsargachromanolI might contribute to the blocking of the collagenase active sites by catalytic chelation of the zinc metal ion $^{[29]}$. This could explain how sargachromanol I might inhibit collagen degradation in the dermis.

In conclusion, the present investigation showed that sargachromanol I was a strong free radical scavenger and inhibited collagen degradation by collagenases. Therefore, these results suggest that sargachromanol I have the potential for preventing skin aging.

\section{Acknowledgements:}

This research was supported by the Basic Research Program through the National Research Foundation of Korea (NRF) funded by the Ministry of Education (No. 2012R1A6A1028677).

\section{Conflicts of interest:}

The authors declare that there is no conflict of interest.

\section{REFERENCES}

1. Jenkins G. Molecular mechanisms of skin ageing. Mech Ageing Dev 2002;123:801-10.

2. Tu Y, Quan T. Oxidative stress and human skin connective tissue aging. Cosmetics 2016;3:1-12.

3. Kaur G, Jabbar Z, Athar M, Alam MS. Punica granatum (pomegranate) flower extract possesses potent anti-oxidant activity and abrogates Fe-NTA induced hepatotoxicity in mice. Food Chem Toxicol 2006;44(7):984-93.

4. Di Lullo GA, Sweeney SM, Korkko J, Ala-Kokko L, San Antonio JD. Mapping the ligand-binding sites and disease- associated mutations on the most abundant protein in the numan, type I collagen. J Biol Chem 2002;277:4223-31.

5. Woessner JF. The family of matrix metalloproteinases. Inhibition of matrix metalloproteinases. Ann NY Acad Sci 1994;732:11-21.

6. Philips N, Conte J, Chen YJ, Natarajan P, Taw M, Keller T, et al. Beneficial regulation of matrix metalloproteinases and their inhibitors, fibrillary collagens and transforming growth factor-beta by Polypodium leucotomos, directly or in dermal fibroblasts, ultraviolet radiated fibroblasts, and melanoma cells. Arch Dermatol Res 2009;301:487-95.

7. Philips N, Keller T, Hendrix C, Hamilton S, Arena R, Tuason $\mathrm{M}$, et al. Regulation of the extracellular matrix remodelling by lutein in dermal fibroblasts, melanoma cells, and ultraviolet radiation exposed fibroblasts. Arch Dermatol Research 2007;299:373-79.

8. Lee CJ, Song EJ, Kim KBWR, Jung JY, Kwak JH, Choi MK, et al. Effect of gamma irradiation in immune activity and physicochemical properties of Myagropsis myagroides water extraction. Korean J Fish Aquat Sci 2011;4:50-7.

9. Cha SH, Ahn GN, Heo SJ, Kim KN, Lee KW, Song $\mathrm{CB}$, et al. Screening of extracts from marine green and brown algae in Jeju for potential marine angiotensin-I converting enzyme (ACE) inhibitory activity. J Korean Soc Food Sci Nutr 2006;35:307-14.

10. Athukorala Y, Lee KW, Kim SK, Jeon YJ. Anticoagulant activity of marine green and brown algae collected from Jeju island in Korea. Bioresour Technol 2007;98:1711-6.

11. Wong CK, Ooi VEC, Ang Jr PO. Hepatoprotective effect of seaweeds methanol extract against carbon tetrachlorideinduced poisoning in rats. Hydrobiologia 2004;512:267-70.

12. Jang KH, Lee BH, Choi BW, Lee HS, Shin J. Chromenes from the brown alga Sargassum siliquastrum. J Nat Prod 2005;68:716-23.

13. Pak WM, Kim KBWR, Kim MJ, Cho JY, Ahn DH. Inhibitory effect of hexane fraction from Myagropsis myagroides on pancreatic amylase in vitro. Microbiol Biotechnol Lett 2014;25:328-33.

14. Wunsch E, Heindrich HG. Zur qutitativen bestimmung der 
collagenase. Hoppe-Seyler's Z Physiol Chem 1963;333:14951.

15. Blois MS. Antioxidant determinations by the use of a stable free radical. Nature 1958;181:1990-2100.

16. Halliwell B, Gutteridge JM. Oxygen toxicity, oxygen radicals, transition metals and disease. Biochem J 1984;219:1-14.

17. Huang XK, Chen S, Xu L, Liu YQ, Deb DK, Platanias LC, et al. Genistein inhibits p38 map kinase activation, matrix metalloproteinase type 2 , and cell invasion in human prostate epithelial cells. Cancer Res 2005;65:3470-8.

18. Rooprai HK, Kandanearatchi A, Maidment SL, Christidou M, Trillo-Pazos G, Dexter DT, et al. Evaluation of the effects of swainsonine, captopril, tangeretin and nobiletin on the biological behaviour of brain tumour cells in vitro. Neuropathol Appl Neurobiol 2001;27:29-39.

19. Kirszberg C, Esquenazi D, Alviano CS, Rumjanek VM. The effect of a catechin-rich extract of Cocos nucifera on lymphocytes proliferation. Phytother Res 2003;17:1054-8.

20. Moon HI, Kim TI, Cho HS, Kim EK. Identification of potential and selective collagenase, gelatinase inhibitors from Crataegus pinnatifida. Bioorg Med Chem Lett 2010;20:991-3.

21. Tang HJ, Martel K, Stribley J, Christman G. The effect of resveratrol on collagen expression in human uterine leiomyoma cells. J Soc Gynecol Investig 2006;13:70a-1a.

22. Nsimba RY, Kikuzaki H, Konishi Y. Ecdysteroids act as inhibitors of calf skin collagenase and oxidative stress. J Biochem Mol Toxic 2008;22:240-50.
23. Iwashima M, Mori J, Ting X, Matsunaga T, Hayashi K, Shinoda $\mathrm{D}$, et al. Antioxidant and antiviral activities of plastoquinones from the brown alga Sargassum micracanthum, and a new chromene derivative converted from the plastoquinones. Biol Pharm Bull 2005;28:374-7.

24. Seo YW, Park KE, Nam TJ. Isolation of a new chromene from the brown alga Sargassum thunbergii. Bull Korean Chem Soc 2007;28:1831-3.

25. Bifulco G, Bruno I, Minale L, Riccio R, Debitus C, Bourdy G, et al. Bioactive prenylhydroquinone sulfates and a novel $\mathrm{C} 31$ furanoterpene alcohol sulfate from the marine sponge, Ircinia Sp. J Nat Prod 1995;58:1444-9.

26. Stonik VA, Makarieva TN, Dimitrenok AS. Sarcochromenol sulfates $\mathrm{A}-\mathrm{C}$ and sarcohydroquinone sulfates $\mathrm{A}-\mathrm{C}$, new natural products from the sponge Sarcotragus spinulosus. J Nat Prod 1992;55:125-60.

27. Kim YH, Kim KS, Han CS, Yang HC, Park SH, Ko KI, et al. Inhibitory effects of natural plants of Jeju Island on elastase and MMP-1 expression. J Cosmet Sci 2007;58:19-33.

28. Zeng G, McCue HM, Mastrangelo L, Millis AJ. Endogeneous TGFbeta activity is modified during cellular aging: effects on matrix metalloproteinase and TIMP-1 expression. Exp Cell Res 1996;228:271-6.

29. Kim JA, Han BN, Kong CS, Kim SK. The chromene sargachromanol E inhibits ultraviolet A-induced ageing of skin in human dermal fibroblasts. Br J Dermatol 2013;168:968-76. 